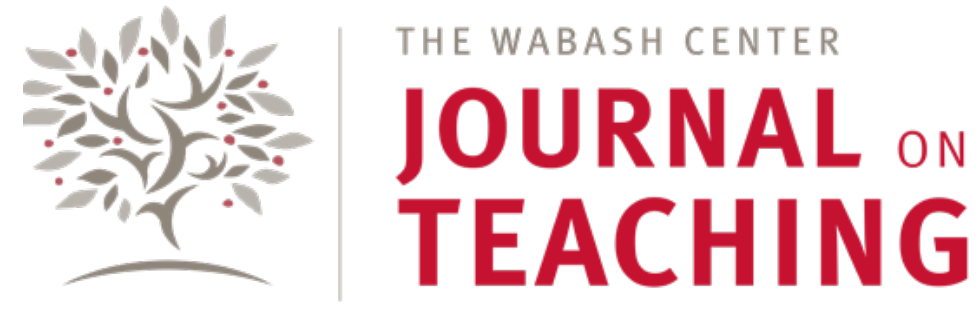

DESIGN \& ANALYSIS

\title{
Building a New Testament Syllabus after the 2016 Elections
}

\author{
Susanna Drake \\ Macalester College
}

\begin{abstract}
After the 2016 elections, students at Macalester College, a small private liberal arts college in Saint Paul, Minnesota, encouraged the faculty and staff to combat hate, sexism, racism, anti-Semitism, and white supremacy in and out of the classroom. These students inspired me to reconsider the way that I taught my introductory New Testament course. In this essay, I present the process by which I redesigned the course to explore not only the historical context of the New Testament texts but also our present political context and the ways it shapes biblical interpretation. The redesigned syllabus includes scholarship representative of feminist, post-colonial, African American, Latinx, Asian-American, Jewish, queer, and other liberationist and identity-based approaches to the study of the New Testament.
\end{abstract}

\section{KEYWORDS}

New Testament, syllabus, inclusion, diversity, biblical interpretation

In the fall of 2017, students at Macalester College, a private liberal arts college in Saint Paul, Minnesota with around 2,100 undergraduates, led a walk-in against hate on our campus. In light of the 2016 elections and increased incidents of hate in our community and nation, students asked faculty members to consider, among other things, how whiteness and white supremacy operated in our classrooms and courses. I am grateful to these students for leading me to recognize the whiteness of my courses, which begins with the syllabi I design. The majority of textbooks, monographs, and articles that I assigned in my classes were written by white-identified scholars. The methodologies that I taught were rooted, in many cases, in white, male, and Eurocentric ways of knowing. I knew I could begin to change my practices and offer more equitable and inclusive learning experiences for my students, and I decided to start by redesigning my course, "Introduction to the New Testament" (Drake 2018c).

I have taught an introductory New Testament course every other year at Macalester for over a decade. My original intention for the course was to introduce students to the New Testament texts in their original contexts, employing historical criticism as my primary method. After the walk-in, I became more aware of the pedagogical problem that I faced: the methodologies and interpretations that I taught in my New Testament course were rooted in a white, mostly male, European, and, historically, antiSemitic model of biblical interpretation. I decided to redesign the course to explore not only the historical context of the New Testament texts but also (and more pressingly) our present political context and the ways it shapes and is shaped by biblical interpretation. I recentered the course on feminist, post-colonial, African American, Latinx, Asian-American, Jewish, queer, and other liberationist and identity-based approaches to the study of the New Testament. The specific learning goal that I had 
for my students was to understand several early Christian documents through a lens that engaged topics of race, sexuality, religion, identity, difference, and power-then and now. My hope for the course was that this new approach would not only introduce students to multiple and diverse perspectives but also enable them to develop more facility in understanding the complexities of identity, difference, hierarchy, and power in the ancient Mediterranean world.

In what follows, I discuss my redesigned syllabus, my learning outcomes for the students, my reasons for including some specific assignments, and the students' and my assessment of what worked well and what could use improvement. The redesign of my introductory New Testament course began with a new title and course description. I also registered to have the course count toward the U.S. Identities and Differences (Macalester College 2020) general education requirement at our college. Not only did this designation align with my new aims for the course, but I also wanted the course to attract students who might not traditionally take a course in biblical studies or religious studies. At Macalester, students who complete the U.S. Identities and Differences requirement will be able to:

- Recognize that group identities and differences are socially constructed or historically contingent;

- Examine forms or forces that create, reflect, maintain, or contest identities and differences;

- Evaluate the significance of identities and differences for life and culture in the United States. (Macalester 2020)

I envisioned that students who were mostly interested in ancient religions would be exposed to ways in which contemporary theories of identity and interpretation shape our understandings of ancient differences and identities. Likewise, students who were mostly interested in issues of identity and difference nationally or globally would learn about how identity, difference, and power functioned in the ancient Mediterranean world. With a joint examination of issues of difference in the ancient Mediterranean and the modern U.S., this class aimed to contextualize discourses of race, ethnicity, gender, sexuality, economic status, religion, and power in their own historical periods (ancient and modern). We studied the social construction of difference and its historical negotiation in biblical times and in the modern U.S. by studying early Christian texts through the lens of scholarship and biblical interpretation from scholars in historically-marginalized groups in the U.S.

Most of the biblical scholarship covered in this course challenged white, Eurocentric biblical interpretation-including the historical-critical method which has become normative for U.S. liberal arts colleges and graduate programs in religion. Students learned not only various methods of biblical interpretation but also how subjective experiences, identities, shared histories, institutionalized privileges, and histories of oppression shaped the reception and use of the New Testament across diverse communities in the U.S.

My syllabus for this class is still a work-in-progress (Drake 2018c). Some of the assignments worked well, some less so. I chose to begin the course with the same set of readings and assignments with which I have always taught my New Testament classes, that is, by reading the work of several prominent (white, male) scholars in the field. Looking back, it is perplexing to me that I began this revamped course in this way, but it also shows me how attached I am to these particular readings and assignments as a way of beginning: Reading Dale Martin's “The Myth of Textual Agency” (2006) which enables students to recognize and discuss “how people mean with texts”; presenting Ja Elsner's chapter on “Art and Religion” (Elsner 1998) to give students a taste for the varieties of pietistic practices in the Roman world and the material culture of the first centuries, C.E.; and reading several essays from the Jewish Annotated New Testament (Levine and Brettler 2011) to understand late second temple Judaism and its cultures and histories.

Two assignments complement the readings from the first two weeks. In the Ancient Avatar assignment (Drake 2018a), students create and present ancient avatars for themselves. These avatars live, work, and worship in the ancient Mediterranean in the first century, C.E., and students get creative in the various ways that they present the daily lives of their avatars to the class (from Instagram feeds to singles ads to dioramas). One student noted that this assignment "helped her, over the course of the semester, to continue to put herself in the frame of mind of someone who lived in that era." It created an opportunity for empathy and learning across difference. The second assignment, the critical terms worksheet (Drake 2018b), presents an opportunity to develop a shared vocabulary among the students and professor. Getting everyone on the same page in regard to the critical vocabulary of the field of biblical studies is, I believe, a necessary first step in creating an equitable and inclusive classroom. In hindsight, I would add more terms to this list to encompass the technical terms from the critical studies of race, gender, sexuality, class, colonialism, and dis/ability.

When I began exploring the histories of feminist/womanist, African-American, Latinx, and Asian-American biblical interpretation, I noticed how many of these interpretive methods drew on the language of liberation theology. I had never 
taught liberation theology before so I needed some guidance from textbooks and encyclopedias. The students and I found the Handbook of U.S. Theologies of Liberation (De La Torre 2004), to be a very helpful resource in learning about the history of liberation theology, its U.S. reception, and its engagement of and influence on biblical interpretation. Several students reported in end-of-course surveys that the group presentations on individual chapters from this handbook were among the most effective and memorable learning experiences of the course. It was their first exposure to the wide diversity of biblical interpretation in the contemporary U.S. as well as the connections among biblical interpretation, liberation movements, and political activism.

One of the challenges in designing this syllabus was striking the right balance between the primary texts and the more recent biblical scholarship and interpretive methods. The students and I found that a good rhythm for the week involved work on the New Testament texts in the beginning of the week (including a lecture on ancient historical contexts of the gospel or letter) and a discussion of the interpretation of that text at the end of the week. In the end of course surveys, some students indicated that I needed to be more consistent with this rhythm to help them organize the new material they were learningboth ancient and modern. In the midterm examination (timed, open-book essays), I asked students to choose to respond to two of four essay prompts, each of which required them to engage select New Testament texts in their ancient contexts and the use of these texts in one or more of the twentieth and twenty-first-century interpreters we had considered to this point in the semester. Students' midterm essays showed me that they had, for the most part, a very good grasp of the primary and secondary texts as well as the ways that social, historical, and political positioning mutually informed biblical interpretation.

Another challenge I faced involved the order in which to present the different approaches to biblical interpretation. Should I assign readings from womanist and feminist biblical interpreters first or should these be intermixed all along? In the end, I had no particular rationale for beginning with liberation theological approaches, then moving to post-colonial, AfricanAmerican, queer, feminist, womanist, and mujerista methods of biblical interpretation, but this ordering is something I would like to reconsider the next time I teach this course. Reading an essay such as Jacquelyn Grant's (1989) “Womanist Theology: Black Women's Experience as a Source for Doing Theology, with Special Reference to Christology" early in the semester is an effective way to introduce students to the intersectionality of identity and the complexity and multilayeredness of systematic oppression. Students found Grant's essay (1989) particularly helpful in drawing links between politics, activism, theology, Christology, and biblical interpretation.

I realized halfway through that my learning goals for the course amounted to more than a semester's worth of work, and some of my ideas were given short shrift. For example, with an additional semester (or in an upper-level version of this course) I would have spent more time studying the methodologies of different interpretive communities. We touched on this briefly in the readings by Vincent Wimbush (1991; 2013), Elisabeth Schüssler Fiorenza (1985), and Gay Byron and Vanessa Lovelace (2016), which enabled us to explore the histories, theories, techniques, and internal diversities of the identity-based approaches to biblical interpretation.

This syllabus is just a starting place for my shift in practice that takes into account students' and teachers' contexts (including the contemporary political contexts) as well as the content of the course (the New Testament documents). At the end of the course, students' comments attested that the engagement of context and content transformed their understanding of not only the New Testament texts but also identity and difference in their more proximate communities. One student indicated that this course helped them "re-examine long held perceptions and assumptions"; another said that the course helped them to "understand different perspectives that [they'd] never considered before" and "see more connections" between the biblical texts under study and the world around them. Another student wrote that this class helped them appreciate "how important biblical interpretation can be for different groups of oppressed peoples." They learned to ask the following sorts of questions: Who gets to create biblical interpretation? How do we differentiate among "better" or "worse" interpretations? And how do methods of biblical interpretation function as claims to power? The redesign of this course has spurred me on to critically examine the whiteness of my other course syllabi and to learn and adopt more techniques to make the learning experiences in my classrooms more diverse, inclusive, and equitable. 


\section{BIBLIOGRAPHY}

Byron, Gay. 2009. "Ancient Ethiopia and the New Testament: Ethnic (Con)texts and Racialized (Sub)texts.” In They Were All Together in One Place: Toward Minority Biblical Criticism, edited by Randall C. Bailey, Tat-siong Benny Liew, and Fernando F. Segovia, 161-90. Atlanta, GA: Society of Biblical Literature.

Byron, Gay, and Vanessa Lovelace. 2016. “Introduction: Methods and the Making of Womanist Biblical Hermeneutics.” In Womanist Interpretations of the Bible: Expanding the Discourse, edited by Gay Byron and Vanessa Lovelace, 1-18. Semeia Studies, Number 85 . Atlanta, GA: SBL Press.

Cohen, Shaye. 2011. “Judaism and Jewishness." In The Jewish Annotated New Testament, edited by Amy-Jill Levine and Marc Zvi Brettler, 513-14. New York, NY: Oxford University Press.

De La Torre, Miguel A., ed. 2004. Handbook of U.S. Theologies of Liberation. St. Louis, MO: Chalice Press.

Drake, Susanna. 2018a. “Jesus, Peter, Paul, and Mary: The Beginnings of Christianity-Ancient Avatar Assignment." Macalester College, St. Paul, MN. https://www.wabashcenter.wabash.edu/wp-content/uploads/2020/05/Drake_ Ancient_Avatar_Assignment.pdf.

Drake, Susanna. 2018b. “Jesus, Peter, Paul, and Mary: The Beginnings of Christianity-Critical Terms Worksheet.” Macalester College, St. Paul, MN. https://www.wabashcenter.wabash.edu/wp-content/uploads/2020/05/Drake_ Critical_Terms_Worksheet.pdf.

Drake, Susanna. 2018c. “Jesus, Peter, Paul, and Mary: The Beginnings of Christianity-Syllabus.” Macalester College, St. Paul, MN. https://www.wabashcenter.wabash.edu/wp-content/uploads/2020/04/The-Beginnings-of-Christianity.pdf.

Elsner, Ja. 1998. “Art and Religion.” In Imperial Rome and Christian Triumph: The Art of the Roman Empire AD 100-450, 199-238. New York, NY: Oxford University Press.

Grant, Jacquelyn. 1989. “Womanist Theology: Black Women’s Experience as a Source for Doing Theology, with Special Reference to Christology." In African American Religious Studies: An Interdisciplinary Anthology, edited by Gayraud S. Wilmore, 208-27. Durham, NC: Duke University Press.

Klawans, Jonathan. 2011. "The Law.” In The Jewish Annotated New Testament, edited by Amy-Jill Levine and Marc Zvi Brettler, 515-18. New York, NY: Oxford University Press.

Levine, Lee. 2011. "The Synagogue.” In The Jewish Annotated New Testament, edited by Amy-Jill Levine and Marc Zvi Brettler, 519-20. New York, NY: Oxford University Press.

Levine, Amy-Jill, and Marc Zvi Brettler, editors. 2011. The Jewish Annotated New Testament. New York, NY: Oxford University Press.

Macalester College. 2020. “U.S. Identities and Differences Designation.” https://www.macalester.edu/epag/gesforms/ usid/.

Martin, Dale. 2006. "The Myth of Textual Agency." In Sex and the Single Savior: Gender and Sexuality in Biblical Interpretation, 1-16. Louisville, KY: Westminster John Knox Press.

Schüssler Fiorenza, Elisabeth. 1985. “Toward a Feminist Critical Method.” In In Memory of Her: A Feminist Theological Reconstruction of Christian Origins, 41-67. New York, NY: Crossroad.

Wimbush, Vincent. 1991. "The Bible and African Americans: An Outline of an Interpretive History." In Stony the Road We Trod, edited by Cain Hope Felder, 81-97. Minneapolis, MN: Fortress Press. 
Wimbush, Vincent. 2013. “Introduction: Knowing Ex-centrics/Ex-centric Knowing.” In Misreading America: Scriptures and Difference, 1-4. New York, NY: Oxford University Press.

\section{ABOUT THE AUTHOR}

Susanna Drake teaches courses in early Christianity, biblical studies, and Women's, Gender, and Sexuality Studies at Macalester College. Her research interests include early Christian and Jewish relations, gender and sexuality in late antiquity, and biblical interpretation in art and text. Her book Slandering the Jew: Sexuality and Difference in Early Christian Texts, was published by University of Pennsylvania Press in 2013. Her current research includes a study of veiling practices in late antiquity. 
